\title{
Studi Optimasi Air Irigasi Bendungan Semantok Untuk Memaksimalkan Luas Layanan Irigasi di Kabupaten Nganjuk
}

\author{
Putri Dita Larasati ${ }^{*}$, Rini Wahyu Sayekti ${ }^{1}$, Widandi Soetopo ${ }^{1}$ \\ ${ }^{1}$ Jurusan Teknik Pengairan, Fakultas Teknik, Universitas Brawijaya, \\ Jalan MT. Haryono No. 167, Malang, 65145, INDONESIA \\ *Korespondensi Email: pdlaras@gmail.com
}

\begin{abstract}
Nganjuk district is quite dry with low rainfall distribution however people still rely on rainfed irrigation including 6 irrigation areas which are Weir Rejoso, Margomulyo, Ngomben, Jati, Jatirejo, and Janeng. This problem makes the total cropping intensity for three times planting period of every irrigation area didn't reach $300 \%$. To anticipate this problem, Semantok Dam was built to provide the discharge of irrigation water needs in the amount of $3.23 \mathrm{~m}^{3} / \mathrm{s}$ for all irrigation areas available in each weir. This study performed optimization with the linear program using solver in Microsoft Excel. The objective function of this model was to optimize the supply provided by the dam and to optimize the potential land area available in the weir irrigation area by the discharge supply and available land area as constraints. In this optimization model, three cropping patterns were planned with a variety of initial planting times for each weir. Based on the optimization result, the selected cropping pattern is the $2^{\text {nd }}$ cropping pattern alternative that starts planting on the $3^{\text {rd }}$ period of December with a total cropping intensity is $300 \%$.
\end{abstract}

Keywords: Cropping pattern, Irrigation, Linear programming, Optimization, Semantok Dam

Abstrak: Kabupaten nganjuk merupakan daerah kering dengan sistem irigasi teknis namun masih mengandalkan irigasi tadah hujan dimana meliputi 6 daerah irigasi bendung yaitu Bendung Rejoso, Margomulyo, Ngomben, Jati, Jatirejo dan Janeng. Sehingga intensitas tanam total untuk tiga kali masa tanam pada setiap daerah irigasi bendung tidak mencapai $300 \%$. Demi mengantisipasi hal ini maka dibangun Bendungan Semantok guna menyuplai debit kebutuhan irigasi sebesar 3,23 $\mathrm{m}^{3} / \mathrm{dt}$ untuk keenam daerah irigasi bendung tersebut. Dalam studi ini dilakukan optimasi dengan program linier menggunakan fasilitas solver pada Microsoft Excel. Fungsi tujuan pada model optimasi ini adalah mengoptimalkan debit suplai pada bendungan dan luas potensial yang ada pada 6 daerah irigasi bendung dengan fungsi kendala yaitu debit suplai bendungan dan luas lahan tersedia. Pada model optimasi ini direncanakan tiga alternatif pola tata tanam dengan perbedaan awal tanam untuk masing-masing bendung. Berdasarkan hasil optimasi maka didapat pola tata tanam terpilih adalah alternatif pola tata tanam ke-II dengan awal tanam Bulan Desember periode III dengan intensitas tanam total $300 \%$. 
Kata kunci: Bendungan Semantok, Irigasi, Optimasi, Pola tata tanam, Program linier

\section{Pendahuluan}

Badan Pusat Statistik menyatakan bahwa sektor pertanian adalah salah satu yang memiliki tenaga kerja terbanyak namun tidak didukung dengan upah pekerjanya [1]. Untuk memperbaiki taraf hidup petani maka diperlukan pembangunan bendungan pada beberapa wilayah Indonesia. Dimana salah satunya di Kabupaten Nganjuk yang merupakan daerah kering yang masih mengandalkan irigasi tadah hujan. Pembangunan Bendungan Semantok dilakukan pada Sungai Semantok yang akan menyuplai 6 bendung meliputi Bendung Rejoso, Margomulyo, Ngomben, Jati, Jatirejo dan Janeng dengan debit suplai irigasi sebesar $3,23 \mathrm{~m}^{3} / \mathrm{dt}$ untuk lahan seluas \pm 1825 ha.

Oleh karena itu dibutuhkan perhitungan optimasi untuk mengoptimalkan suplai air irigasi yang diberikan agar kebutuhan air irigasi terpenuhi dan intensitas tanam meningkat. Penelitian ini ditekankan pada masalah (a) bagaimana intensitas tanam kondisi eksisting; (b) bagaimana neraca air kondisi eksisting; (c) berapa luas tanam paling optimal dari alternatif rencana setelah optimasi; dan (d) bagaimana intensitas tanam dan kondisi kebutuhan air alternatif rencana setelah optimasi serta alternatif yang dipilih. Studi serupa pernah dilakukan oleh Rini Wahyu Sayekti (2010) berlokasi di Dam Jatimlerek Kabupaten Jombang [2].

Tujuan dari penelitian ini adalah untuk memaksimalkan luas layanan irigasi yang tersedia melalui berbagai alternatif pola tata tanam dengan perbedaan awal tanam dengan menerapkan program linier dengan dibantu fasilitas solver dari Microsoft Excel sehingga diharapkan didapatkan luas tanam paling optimal agar intensitas tanam meningkat.

\section{Bahan dan Metode}

Lokasi studi berada pada Daerah Irigasi Bendungan Semantok, Kabupaten Nganjuk Provinsi Jawa Timur yang memiliki beberapa bendung dengan areal layanan irigasi di desa-desa yang berada di Kecamatan Rejoso dan Kecamatan Sukomoro. Pada Gambar 1 dijelaskan Daerah Irigasi (D.I) yang direncanakanakan tersuplai debit dari bendungan adalah D.I Rejoso yang terdiri dari bendung-bendung yang mempunyai areal layanan berbeda (UPTD Wilayah Rejoso), sebagai berikut : D.I Bendung Rejoso Kanan dan Kiri total 465 ha, D.I Bendung Margomulyo 154 ha, D.I Bendung Jatirejo 321 ha (mutasi menjadi 316 ha), D.I Bendung Janeng 254 ha (mutasi menjadi 245 ha), D.I Bendung Jati 227 ha, dan D.I Bendung Ngomben 400 ha dimana tersedia irigasi teknis seluas 122 ha [3].

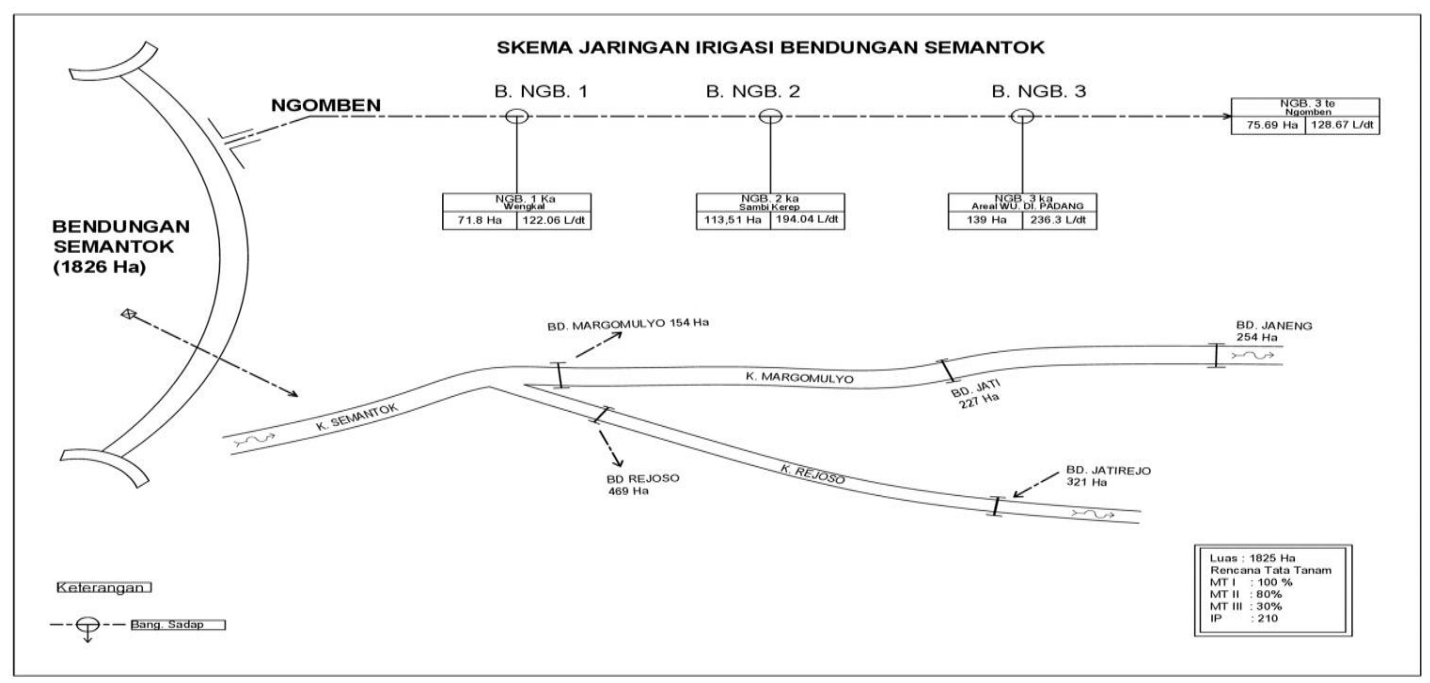

Gambar 1: Skema Jaringan Irigasi Bendungan Semantok 


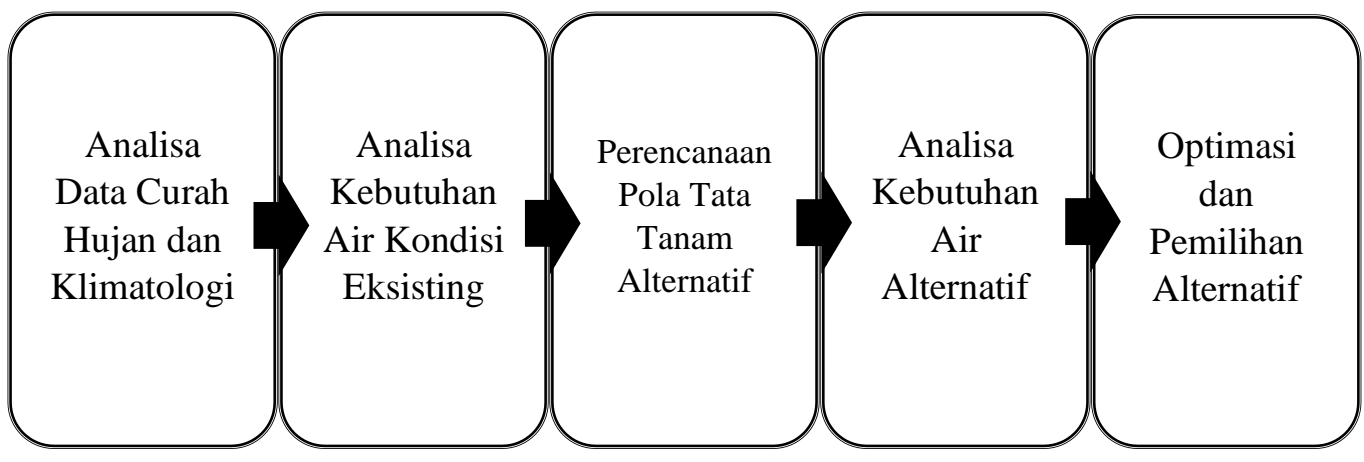

\subsection{Analisis Data Curah Hujan dan Klimatologi}

Data curah hujan tahunan selama 15 tahun dari Stasiun Hujan Kedungpingit, Gondang dan Rejoso diuji konsistensinya dengan metode kurva massa ganda [4]. Data curah hujan tahunan tersebut selanjutnya diuji kualitas datanya menggunakan statika sebagai bahan untuk analisis hidrologi [5]. Menentukan tipe iklim daerah studi menggunakan klasifikasi iklim Oldeman [6] untuk mengetahui pola tata tanam yang sesuai. Curah hujan andalan dihitung dengan metode Harza Engineering Corp International serta curah hujan efektif dihitung menggunakan metode yang ditetapkan oleh Standar Kriteria Perencanaan Irigasi pada KP 01 [7]. Mencari nilai evapotranspirasi potensial dengan menggunakan Metode Penman Modifikasi [8]. Perhitungan penyiapan lahan digunakan metode Van de Goor dan Ziljistra mengacu pada KP-01 [7].

\subsection{Analisis Kebutuhan Air Kondisi Eksisting}

Menghitung kebutuhan air irigasi pada 6 bendung dengan metode perhitungan mengikuti aturan pada Standar Kriteria Perencanaan Irigasi pada KP-01 [7]. Rumus untuk menghitung kebutuhan air irigasi dijabarkan pada Persamaan 1 dan Persamaan 2.

$$
N F R=E t c+P-\operatorname{Reff}+W L R \quad \text { Pers. } 1
$$

Dengan :

NFR = Netto Field Water Requirement, kebutuhan air bersih di sawah $(\mathrm{mm} /$ hari)

Etc = evapotranspirasi potensial $(\mathrm{mm} / \mathrm{hari})$

$P \quad=$ perkolasi $(\mathrm{mm} / \mathrm{hari})$

Reff $=$ curah hujan efektif $(\mathrm{mm} /$ hari)

$W L R=$ pergantian lapisan $\operatorname{air}(\mathrm{mm} / \mathrm{hari})$

$$
I R=N F R / e \quad \text { Pers. } 2
$$

Dengan :

$I R=$ kebutuhan air irigasi $\left(\mathrm{m}^{3} / \mathrm{dtk} / \mathrm{hari}\right)$

$e \quad=$ efisiensi irigasi keseluruhan

Nilai efisiensi irigasi yang digunakan dalam studi ini mengacu pada Bagian penunjang untuk Standar Perencanaan Irigasi Dep. PU 1986 dalam buku Bardan (2014) [9] adalah sebagai berikut.

1. Efisiensi saluran primer sebesar $90 \%$ 
2. Efisiensi saluran sekunder sebesar $90 \%$

3. Efisiensi saluran tersier sebesar $80 \%$

Sehingga besar nilai efisiensi total keseluruhan adalah $90 \%$ x $90 \%$ x $80 \%=65 \%$

Tabel 1: Laju Perkolasi untuk Berbagai Tekstur Tanah (OTCA,1974)

\begin{tabular}{cc}
\hline Tekstur Tanah & Perkolasi (mm/hari) \\
\hline Lempung Berpasir & $3-6$ \\
\hline Lempung & $2-3$ \\
\hline Liat Lempung & $1-2$ \\
\hline
\end{tabular}

Jenis tanah daerah studi adalah lempung lanau maka menurut Wirosoedarmo pada Tabel 1 laju perkolasi berbagai tekstur tanah digunakan nilai perkolasi sebesar $2 \mathrm{~mm} /$ hari [10]. Nilai WLR yang digunakan sebesar $50 \mathrm{~mm}$ selama 40 hari atau 1,25 mm/hari.

Menurut data yang didapat dari UPTD PSDA Bening Kabupaten Nganjuk, rekap luas area irigasi pada pola tata tanam daerah irigasi bendung ditampilkan pada Tabel 2. Selain itu dibutuhkan juga data rekapitulasi debit pemberian pada tiap bendung kondisi eksisting tahun 2018 untuk perbandingan perhitungan kondisi eksisting [11].

Tabel 2: Rekap Luas Area Irigasi Pola Tata Tanam Daerah Irigasi Bendung

\begin{tabular}{|c|c|c|c|c|c|c|c|}
\hline Bendung & \multicolumn{2}{|c|}{$\begin{array}{c}\text { Masa Tanam I } \\
\text { (ha) }\end{array}$} & \multicolumn{2}{|c|}{$\begin{array}{c}\begin{array}{c}\text { Masa Tanam II } \\
\text { (ha) }\end{array} \\
\end{array}$} & \multicolumn{2}{|c|}{$\begin{array}{c}\text { Masa Tanam III } \\
\text { (ha) }\end{array}$} & \multirow{3}{*}{$\begin{array}{c}\begin{array}{c}\text { Luas Tota } \\
\text { (ha) }\end{array} \\
465\end{array}$} \\
\hline \multirow{2}{*}{ Rejoso } & Padi & 449 & Padi & 378 & Padi & 6 & \\
\hline & Jagung & 16 & Kedelai & 87 & Jagung & 459 & \\
\hline \multirow{2}{*}{ Margomulyo } & Padi & 77 & Padi & 63 & Padi & 10 & \multirow{2}{*}{154} \\
\hline & Padi & 77 & Padi & 91 & Jagung & 144 & \\
\hline \multirow{2}{*}{ Ngomben } & Padi & 117 & Jagung & 97 & Jagung & 92 & \multirow{2}{*}{122} \\
\hline & Jagung & 5 & Kedelai & 25 & Kedelai & 30 & \\
\hline \multirow{2}{*}{ Jati } & Padi & 113.5 & Padi & 212 & Kedelai & 150 & \multirow{2}{*}{227} \\
\hline & Padi & 113.5 & Kedelai & 15 & Jagung & 77 & \\
\hline \multirow{2}{*}{ Jatirejo } & Padi & 296 & Padi & 281 & Kedelai & 200 & \multirow{2}{*}{316} \\
\hline & Kedelai & 20 & Kedelai & 35 & Jagung & 116 & \\
\hline \multirow{2}{*}{ Janeng } & Padi & 228 & Padi & 210 & Kedelai & 155 & \multirow{2}{*}{245} \\
\hline & Kedelai & 17 & Kedelai & 35 & Jagung & 90 & \\
\hline
\end{tabular}

\subsection{Perencanaan Pola Tata Tanam Alternatif}

Merencanakan pola tata tanam alternatif dengan variasi awal tanam berdasarkan curah hujan andalan, pola tata tanam kondisi eksisting dan kondisi neraca air kondisi eksisting. Perencanaan pola tata tanam alternatif berdasarkan pada kondisi curah hujan andalan lebih jelas pada Gambar 2, Gambar 3 dan Gambar 4. 


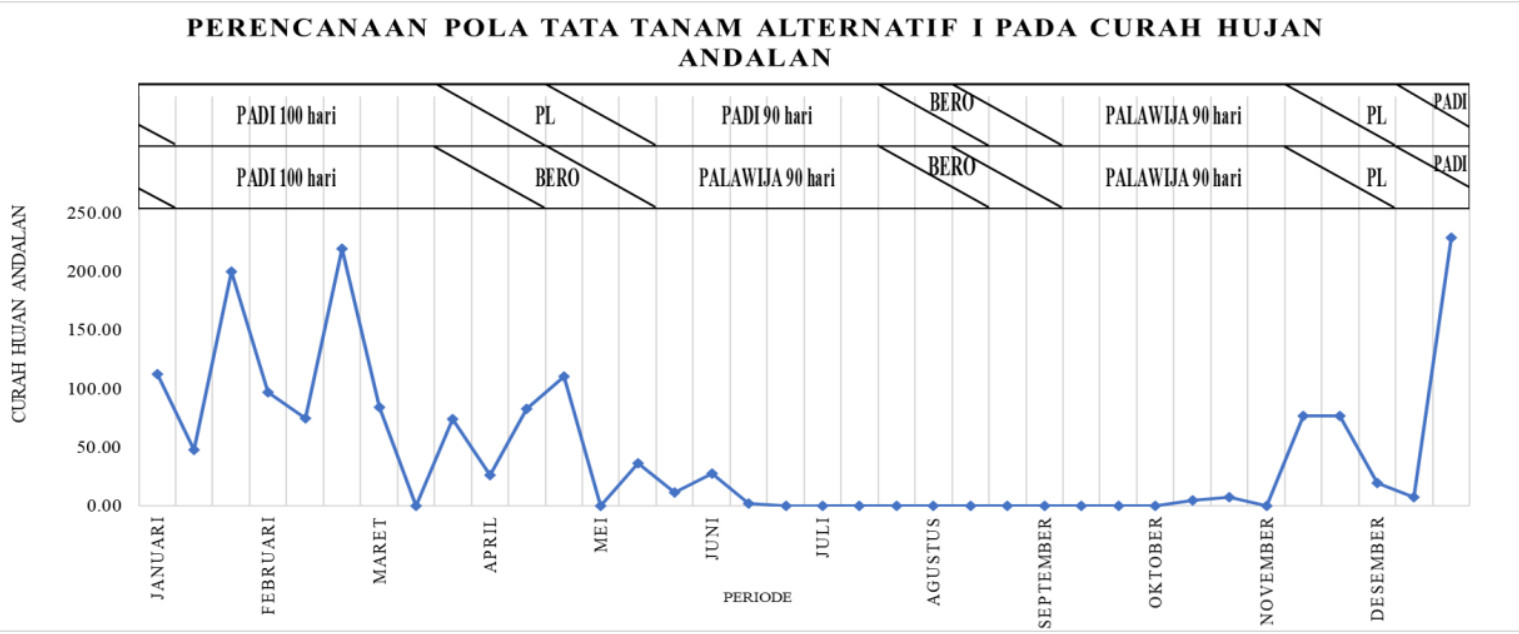

Gambar 2: Rencana Pola Tata Tanam Alternatif I

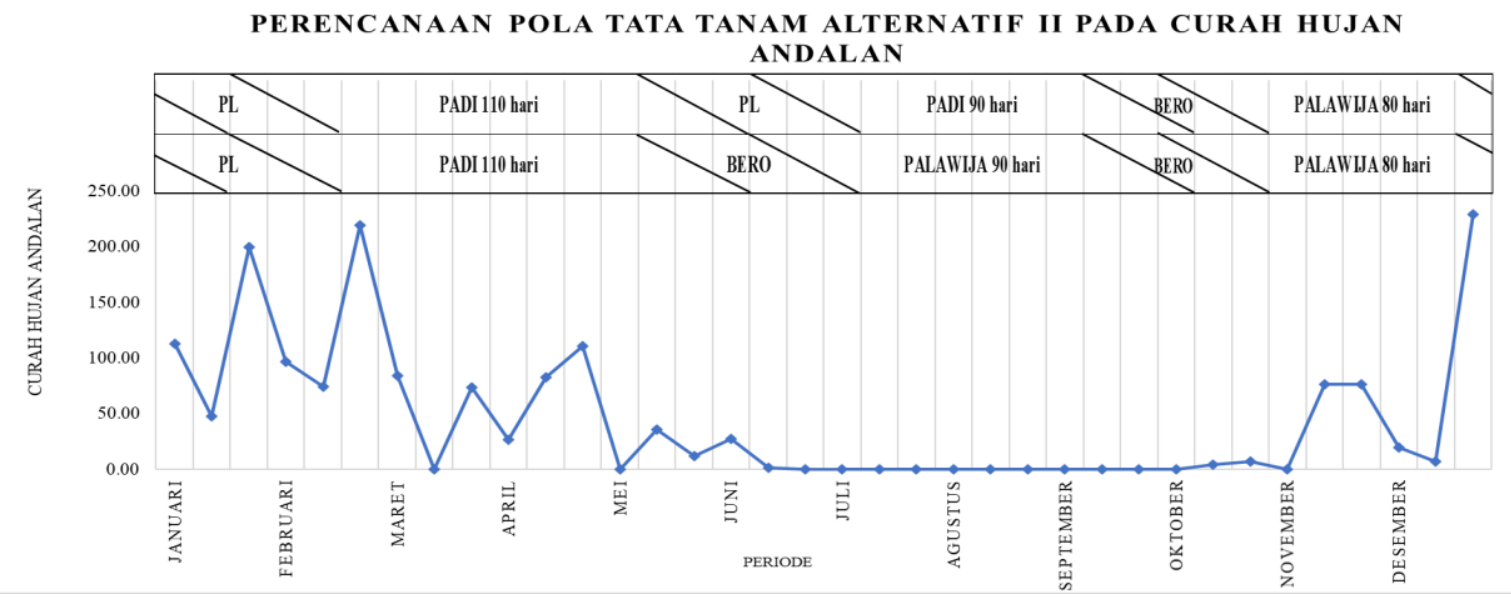

Gambar 3: Rencana Pola Tata Tanam Alternatif II

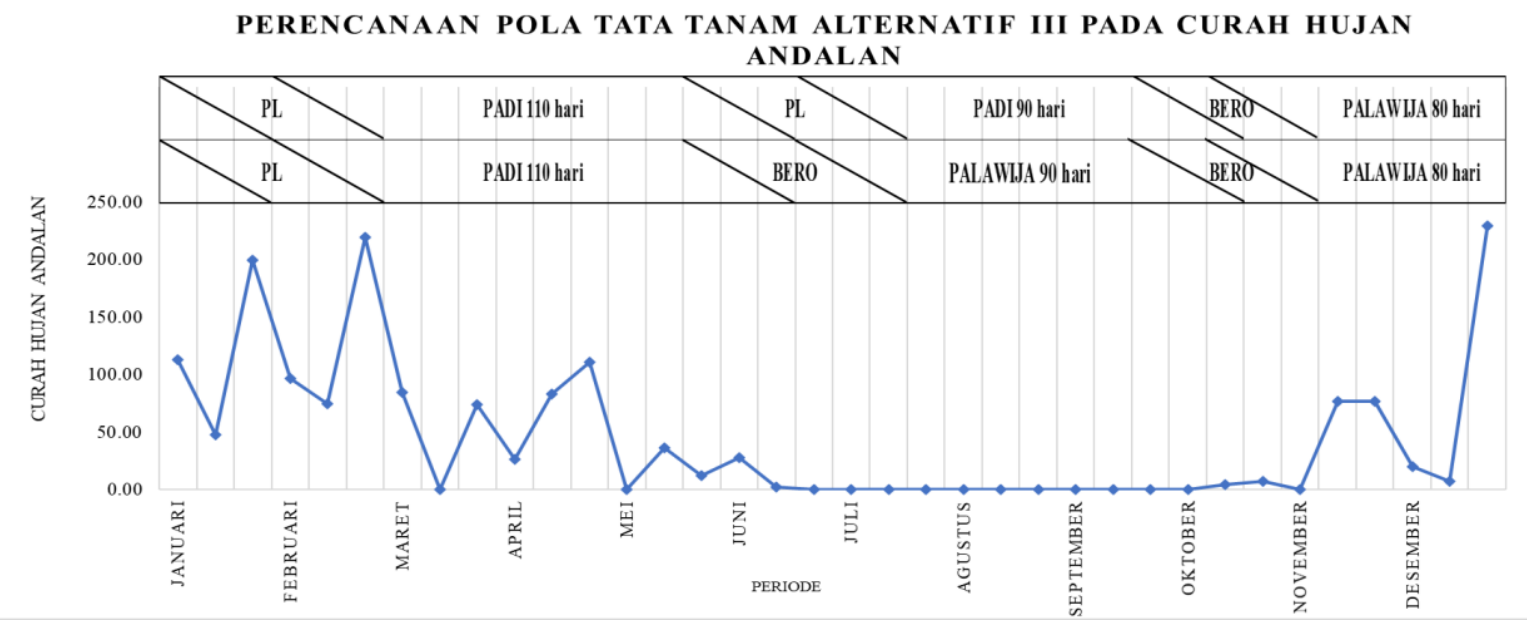

Gambar 4: Rencana Pola Tata Tanam Alternatif III

\subsection{Skenario Optimasi}

Teknik optimasi berkendala ada bermacam-macam pendekatan, untuk konteks pendekatan sumber daya air umumnya dipakai Linier Programming [12]. Perumusan model optimasi dengan program linier menggunakan fasilitas solver pada Microsoft Excel. Program linier dirumuskan dalam variabel putusan 
yaitu luas tanam optimal dengan fungsi tujuan volume kebutuhan air maksimum pada persamaan 3 dan sistem kendala debit suplai bendungan dan luas tanam maksimum pada Persamaan 4 dan 5 .

Variabel Putusan

$$
\begin{aligned}
& x_{n}=\text { Variabel keputusan (luas tanam per tanaman tiap musim tanam) (ha) } \\
& x_{p n}=\text { luas tanam padi (ha) } \\
& x_{j n}=\text { luas tanam jagung (ha) } \\
& x_{k n}=\text { luas tanam kedelai (ha) }
\end{aligned}
$$

Fungsi Tujuan

Sistem Kendala

$$
Z=\sum_{n=1}^{n} C_{m n} X_{m n} \quad \text { Pers. } 3
$$

$$
\begin{array}{ll}
\sum_{n=1}^{n} a_{m} x_{n} \leq b_{s} & \text { Pers. } 4 \\
\sum_{n=1}^{n} X_{m n} \leq X_{t} & \text { Pers. } 5
\end{array}
$$

\subsection{Pemilihan Alternatif}

Pemilihan alternatif pola tata tanam berdasarkan kondisi intensitas tanam, luas tanam, dan debit kebutuhan air irigasi yang paling optimal dan sesuai untuk debit suplai yang diberikan bendungan.

\section{Hasil dan Pembahasan}

\subsection{Analisis Data Curah Hujan dan Klimatologi}

Analisa data curah hujan terdiri dari pengujian konsistensi data dengan metode kurva massa ganda dan pengujian data runtut waktu menggunakan statika hasilnya direkap pada Tabel 3.

Tabel 3: Rekap Hasil Analisa Data Curah Hujan

\begin{tabular}{llll}
\hline Jenis Uji & St. Kedungpingit & St. Gondang & St. Rejoso \\
\hline Kurva Massa Ganda & Konsisten & $\begin{array}{l}\text { Tidak Konsisten } \\
\text { (Dikoreksi) }\end{array}$ & Konsisten \\
\hline Uji Ketiadaan Trend & Tidak Ada Trend & Tidak Ada Trend & Tidak Ada Trend \\
\hline Uji Stasioner (Uji F dan t) & $\begin{array}{l}\text { Varian stabil, data } \\
\text { homogen }\end{array}$ & $\begin{array}{l}\text { Varian stabil, data } \\
\text { homogen }\end{array}$ & $\begin{array}{l}\text { Varian stabil, data } \\
\text { homogen }\end{array}$ \\
\hline Uji Persistensi & Data Independent & Data Independent & Data Independent \\
\hline
\end{tabular}

Menurut klasifikasi iklim Oldeman maka daerah studi tergolong tipe utama tipe C dan subdivisi ke 3. Artinya iklim pada daerah studi termasuk pada tipe $\mathrm{C} 3$ dimana setahun hanya dapat satu kali padi dan penanaman palawija yang kedua harus hati-hati jangan jatuh pada bulan kering. Hasil klasifikasi ini digunakan untuk dijadikan dasaran untuk perencanaan pola tata tanam baru.

Perhitungan evapotranspirasi potensial menggunakan metode Penmann Modifikasi menggunakan data klimatologi selama empat tahun dari Stasiun Klimatologi Sawahan maka didapatkan nilai Eto pada Tabel 4.

Tabel 4: Rekapitulasi Hasil Perhitungan Nilai Evapotraspirasi Potensial

\begin{tabular}{ccccccccccccc}
\hline \multirow{2}{*}{ Parameter } & \multicolumn{10}{c}{ Bulan } \\
\cline { 2 - 13 } & Jan & Febr & Maret & April & Mei & Juni & Juli & Agust & Sept & Okt & Nov & Des \\
\hline Eto (mm/hari) & 2.49 & 2.34 & 2.25 & 1.61 & 1.52 & 1.48 & 1.56 & 1.90 & 2.33 & 2.62 & 2.46 & 2.26 \\
\hline Eto (mm/bulan) & 77.25 & 65.65 & 69.89 & 48.42 & 47.21 & 44.35 & 48.45 & 58.85 & 69.98 & 81.21 & 73.94 & 70.05 \\
\hline
\end{tabular}


Perhitungan penyiapan lahan untuk padi menggunakan metode Van de Goor dan Zijltra dalam Dirjen Pengairan, Departemen Pekerjaan Umum, 1986 dengan hasil dijabarkan pada Tabel 5.

Tabel 5: Rekap Hasil Perhitungan Penyiapan Lahan

\begin{tabular}{ccccccccccccc}
\hline Parameter & \multicolumn{10}{c}{ Bulan } \\
\cline { 2 - 12 } & Jan & Feb & Maret & April & Mei & Juni & Juli & Agust & Sept & Okt & Nov & Des \\
\hline $\begin{array}{c}\text { PL } \\
\text { (mm/hari) }\end{array}$ & 12.56 & 12.46 & 12.41 & 12.01 & 11.95 & 11.92 & 11.97 & 12.18 & 12.46 & 12.64 & 12.54 & 12.41 \\
\hline
\end{tabular}

\subsection{Analisis Kebutuhan Air Kondisi Eksisting}

Analisis kebutuhan air irigasi menghasilkan debit total kebutuhan air di intake sesuai dengan aturan pada KP-01 selanjutnya dibandingkan dengan data debit pemberian pada bendung selama setahun untuk mendapatkan persentase kebutuhan air irigasi terpenuhi sebelum mendapat suplai bendungan dipaparkan pada Tabel 6 .

Tabel 6: Persentase Kebutuhan Air Irigasi Terpenuhi Sebelum Mendapat Suplai Bendungan

\begin{tabular}{cc}
\hline Bendung & Presentase Terpenuhi \\
\hline Rejoso & $72 \%$ \\
Margomulyo & $86 \%$ \\
Ngomben & $94 \%$ \\
Jati & $78 \%$ \\
Jatirejo & $58 \%$ \\
Janeng & $50 \%$ \\
\hline
\end{tabular}

Dari rekapitulasi bahwa belum $100 \%$ dari kebutuhan air irigasi terpenuhi hanya dari air pemberian bendung sehingga diperlukan suplai tambahan dari Bendungan Semantok.

\subsection{Analisis Kebutuhan Air Alternatif}

Pola tata tanam alternatif direncanakan dengan pola tata tanam padi-padi-palawija dengan palawija berupa jagung dan kedelai. Luas tanam untuk setiap tanamannya disesuaikan dengan luas tersedia setelah mutasi. Alternatif direncanakan menjadi tiga variasi awal tanam yaitu alternatif ke-I dengan awal tanam Bulan November periode II, alternatif ke-II dengan awal tanam Bulan Desember periode III serta alternatif ke-III dengan awal tanam Bulan Januari periode I. Setelah itu dihitung debit kebutuhan air irigasi pada setiap alternatif sesuai dengan Standart Kriteria Perencanaan Irigasi KP-01 maka didapatkan debit kebutuhan irigasi seperti pada Gambar 2.

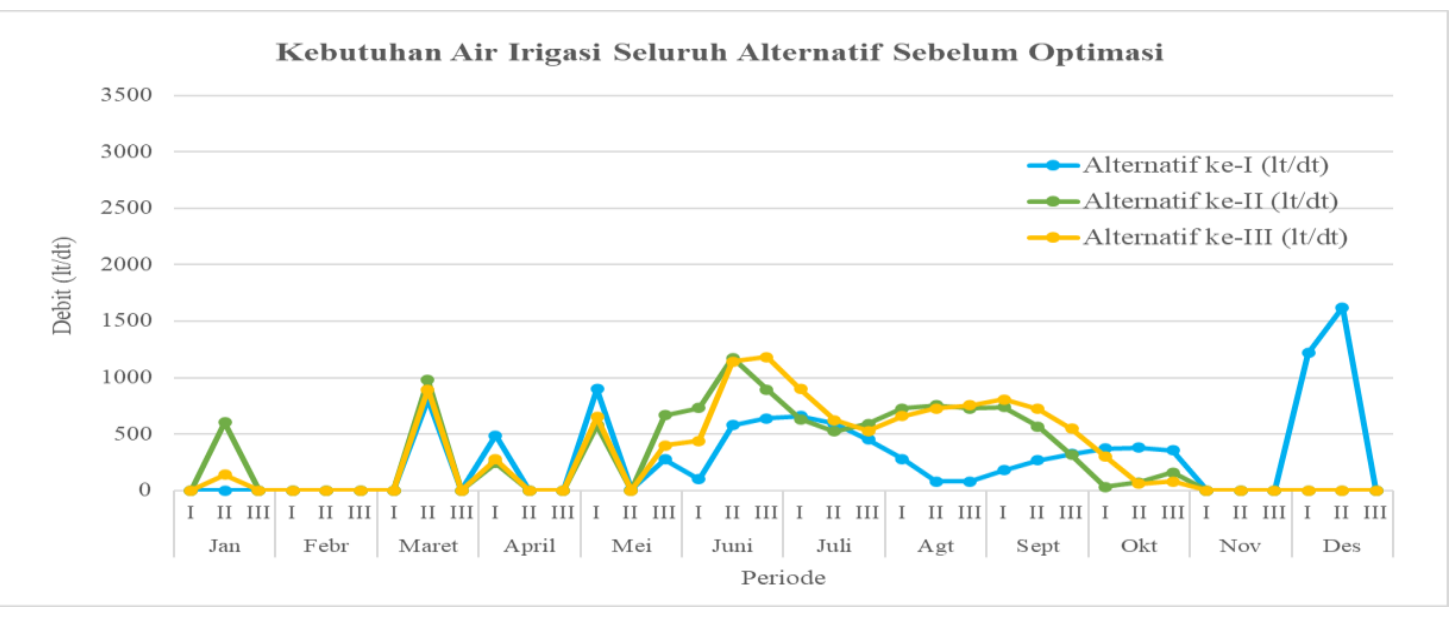

Gambar 5: Debit Kebutuhan Air Irigasi Seluruh Alternatif Sebelum Optimasi 


\subsection{Optimasi dengan Program Linier}

Proses optimasi dilakukan dengan program linier menggunakan fasilitas solver pada Microsoft Excel dengan model matematika dengan perumusan yang terdiri dari:

a. Variabel Putusan

Variabel keputusannya adalah penentuan luas tanam pada tiap jenis tanaman dalam setiap daerah irigasi suatu bendung.

$X_{P 1} \quad=$ Luasan tanam padi pada Bendung Rejoso (ha)

$X_{J 1} \quad=$ Luasan tanam jagung pada Bendung Rejoso (ha)

$X_{K 1} \quad=$ Luasan tanam kedelai pada Bendung Rejoso (ha)

$X_{P 2} \quad=$ Luasan tanam padi pada Bendung Margomulyo (ha)

$X_{J 2}=$ Luasan tanam jagung pada Bendung Margomulyo (ha)

$X_{K 2} \quad=$ Luasan tanam kedelai pada Bendung Margomulyo (ha)

$X_{P 3} \quad=$ Luasan tanam padi pada Bendung Ngomben (ha)

$X_{J 3} \quad=$ Luasan tanam jagung pada Bendung Ngomben (ha)

$X_{K 3} \quad=$ Luasan tanam kedelai pada Bendung Ngomben (ha)

$X_{P 4} \quad=$ Luasan tanam padi pada Bendung Jati (ha)

$X_{J 4} \quad=$ Luasan tanam jagung pada Bendung Jati (ha)

$X_{K 4} \quad=$ Luasan tanam kedelai pada Bendung Jati (ha)

$X_{P 5} \quad=$ Luasan tanam padi pada Bendung Jatirejo (ha)

$X_{J 5} \quad=$ Luasan tanam jagung pada Bendung Jatirejo (ha)

$X_{K 5} \quad=$ Luasan tanam kedelai pada Bendung Jatirejo (ha)

$X_{P 6} \quad=$ Luasan tanam padi pada Bendung Janeng (ha)

$X_{J 6} \quad=$ Luasan tanam jagung pada Bendung Janeng (ha)

$X_{K 6} \quad=$ Luasan tanam kedelai pada Bendung Janeng (ha)

b. Fungsi Tujuan

Fungsi tujuan yang ingin dicapai adalah memaksimalkan besar volume kebutuhan air dari suplai yang diberikan bendungan dan luas tanaman pada tiap musim tanam pada semua bendung. Musim Tanam I (Kebutuhan Air Irigasi Maksimum pada Bulan Desember periode II)

$$
\begin{aligned}
Z_{I}= & \left(A_{1} \cdot X_{P 1}+B_{1} \cdot X_{J 1}+C_{1} \cdot X_{K 1}\right)+\left(A_{2} \cdot X_{P 2}+B_{2} \cdot X_{J 2}+C_{2} \cdot X_{K 2}\right)+\left(A_{3} \cdot X_{P 3}+B_{3} \cdot X_{J 3}+\right. \\
& \left.C_{3} \cdot X_{K 3}\right)+\left(A_{4} \cdot X_{P 4}+B_{4} \cdot X_{J 4}+C_{4} \cdot X_{K 4}\right)+\left(A_{5} \cdot X_{P 5}+B_{5} \cdot X_{J 5}+C_{5} \cdot X_{K 5}\right)+ \\
& \left(A_{6} \cdot X_{P 6}+B_{6} \cdot X_{J 6}+C_{6} \cdot X_{K 6}\right)
\end{aligned}
$$

Musim Tanam II (Kebutuhan Air Irigasi Maksimum pada Bulan Mei periode I)

$$
\begin{aligned}
Z_{I I}= & \left(A_{7} \cdot X_{P 7}+B_{7} \cdot X_{J 7}+C_{7} \cdot X_{K 7}\right)+\left(A_{8} \cdot X_{P 8}+B_{8} \cdot X_{J 8}+C_{8} \cdot X_{K 8}\right)+\left(A_{9} \cdot X_{P 9}+B_{9} \cdot X_{J 9}+\right. \\
& \left.C_{9} \cdot X_{K 9}\right)+\left(A_{10} \cdot X_{P 10}+B_{10} \cdot X_{J 10}+C_{10} \cdot X_{K 10}\right)+\left(A_{11} \cdot X_{P 11}+B_{11} \cdot X_{J 11}+C_{11} \cdot X_{K 11}\right)+ \\
& \left(A_{12} \cdot X_{P 12}+B_{12} \cdot X_{J 12}+C_{12} \cdot X_{K 12}\right)
\end{aligned}
$$

Musim Tanam III (Kebutuhan Air Irigasi Maksimum pada Bulan Juli periode III)

$$
\begin{aligned}
Z_{I I I}= & \left(A_{13} \cdot X_{P 13}+B_{13} \cdot X_{J 13}+C_{13} \cdot X_{K 13}\right)+\left(A_{14} \cdot X_{P 14}+B_{14} \cdot X_{J 14}+C_{14} \cdot X_{K 14}\right)+ \\
& \left(A_{15} \cdot X_{P 15}+B_{15} \cdot X_{J 15}+C_{15} \cdot X_{K 15}\right)+\left(A_{16} \cdot X_{P 16}+B_{16} \cdot X_{J 16}+C_{16} \cdot X_{K 16}\right)+ \\
& \left(A_{17} \cdot X_{P 17}+B_{17} \cdot X_{J 17}+C_{17} \cdot X_{K 17}\right)+\left(A_{18} \cdot X_{P 18}+B_{18} \cdot X_{J 18}+C_{18} \cdot X_{K 18}\right)
\end{aligned}
$$

c. Sistem Kendala

Variabel yang menjadi pembatas tujuan utama antara lain luas baku sawah yang tersedia pada tiap bendung dan total ketersediaan air suplai dari bendungan untuk enam bendung yaitu sebesar $3,23 \mathrm{~m}^{3} / \mathrm{dt}$. Luas Lahan

$X_{P 1}+X_{J 1}+X_{K 1} \leq X_{T 1}($ Musim Tanam I) 
$X_{P 7}+X_{J 7}+X_{K 7} \leq X_{T 1}$ (Musim Tanam II)

$X_{P 13}+X_{J 13}+X_{K 13} \leq X_{T 1}$ (Musim Tanam III)

$X_{T 1}=$ Luas total baku Daeran Irigasi Bendung Rejoso 465 ha

$X_{P 2}+X_{J 2}+X_{K 2} \leq X_{T 2}($ Musim Tanam I)

$X_{P 8}+X_{J 8}+X_{K 8} \leq X_{T 2}($ Musim Tanam II)

$X_{P 14}+X_{J 14}+X_{K 14} \leq X_{T 2}$ (Musim Tanam III)

$X_{T 2}=$ Luas total baku Daeran Irigasi Bendung Margomulyo 154 ha

$X_{P 3}+X_{J 3}+X_{K 3} \leq X_{T 3}($ Musim Tanam I $)$

$X_{P 9}+X_{J 9}+X_{K 9} \leq X_{T 3}($ Musim Tanam II)

$X_{P 15}+X_{J 15}+X_{K 15} \leq X_{T 3}$ (Musim Tanam III)

$X_{T 3}=$ Luas total baku Daeran Irigasi Bendung Ngomben 400 ha

$X_{P 4}+X_{J 4}+X_{K 4} \leq X_{T 4}($ Musim Tanam I)

$X_{P 10}+X_{J 10}+X_{K 10} \leq X_{T 4}($ Musim Tanam II)

$X_{P 16}+X_{J 16}+X_{K 16} \leq X_{T 4}$ (Musim Tanam III)

$X_{T 4}=$ Luas total baku Daeran Irigasi Bendung Jati 227 ha

$X_{P 5}+X_{J 5}+X_{K 5} \leq X_{T 5}$ (Musim Tanam I)

$X_{P 11}+X_{J 11}+X_{K 11} \leq X_{T 5}($ Musim Tanam II)

$X_{P 16}+X_{J 16}+X_{K 16} \leq X_{T 5}$ (Musim Tanam III)

$X_{T 5}=$ Luas total baku Daeran Irigasi Bendung Jatirejo 316 ha

$X_{P 6}+X_{J 6}+X_{K 6} \leq X_{T 6}($ Musim Tanam I)

$X_{P 12}+X_{J 12}+X_{K 12} \leq X_{T 6}$ (Musim Tanam II)

$X_{P 18}+X_{J 18}+X_{K 18} \leq X_{T 6}($ Musim Tanam III)

$X_{T 6}=$ Luas total baku Daeran Irigasi Bendung Janeng 245 ha

$X_{T 1}+X_{T 2}+X_{T 3}+X_{T 4}+X_{T 5}+X_{T 6} \leq X_{T o t a l}$

$X_{\text {Total }}=$ Luas Total seluruh Daerah Irigasi Bendungan Semantok yang tersedia 1807 ha

Debit Air Suplai Tersedia ( $\left.\mathrm{Q}_{\text {suplai }}\right)$

Qsuplai setiap periode 10 harian untuk seluruh bendung pada Daerah Irigasi Bendungan Semantok sebesar $3,23 \mathrm{~m}^{3} / \mathrm{dtk}$

$\sum_{n=1}^{6} a_{p 1} x_{p 1}+a_{j 1} x_{j 1}+a_{k 1} x_{k 1}+\cdots+a_{p n} x_{p n}+a_{j n} x_{j n}+a_{k n} x_{k n} \leq 3,23 \mathrm{~m}^{3} / \mathrm{dtk}$ (Musim Tanam I)

$\sum_{n=7}^{12} a_{p 7} x_{p 7}+a_{j 7} x_{j 7}+a_{k 7} x_{k 7}+\cdots+a_{p n} x_{p n}+a_{j n} x_{j n}+a_{k n} x_{k n} \leq 3,23 \mathrm{~m}^{3} / \mathrm{dtk}$ (Musim Tanam II)

$\sum_{n=13}^{18} a_{p 13} x_{p 13}+a_{j 13} x_{j 13}+a_{k 13} x_{k 13}+\cdots+a_{p n} x_{p n}+a_{j n} x_{j n}+a_{k n} x_{k n} \leq 3,23 \mathrm{~m}^{3} / \mathrm{dtk}$ (Musim Tanam III) 
Setelah merumuskan model matematika untuk optimasi pada setiap alternatif maka selanjutnya dilakukan proses optimasi menggunakan fasilitas Solver pada Microsoft Excel. Hasil optimasi didapatkan luas tanam tiap bendung untuk setiap alternatif ditampilkan pada Tabel 8. Didapatkan pula volume kebutuhan air irigasi maksimum untuk ketiga alternatif ditampilkan pada Tabel 9.

Tabel 7: Luas Tanam Kondisi Alternatif Setelah Proses Optimasi dalam hektar (ha)

\begin{tabular}{ccccccccccccc}
\hline \multirow{2}{*}{ Bendung } & \multicolumn{4}{c}{ Alternatif I (ha) } & \multicolumn{3}{c}{ Alternatif II (ha) } & \multicolumn{4}{c}{ Alternatif III (ha) } \\
\cline { 2 - 13 } & MT I & MT II & MT III & Total & MT I & MT II & MT III & Total & MT I & MT II & MT III & Total \\
\hline Rejoso & 465 & 465 & 465 & $\mathbf{1 3 9 5}$ & 465 & 465 & 465 & $\mathbf{1 3 9 5}$ & 465 & 465 & 465 & $\mathbf{1 3 9 5}$ \\
\hline Margomulyo & 154 & 154 & 154 & $\mathbf{4 6 2}$ & 154 & 154 & 154 & $\mathbf{4 6 2}$ & 154 & 154 & 154 & $\mathbf{4 6 2}$ \\
\hline Ngomben & 400 & 400 & 400 & $\mathbf{1 2 0 0}$ & 400 & 400 & 400 & $\mathbf{1 2 0 0}$ & 400 & 400 & 400 & $\mathbf{1 2 0 0}$ \\
\hline Jati & 227 & 227 & 227 & $\mathbf{6 8 1}$ & 227 & 227 & 227 & $\mathbf{6 8 1}$ & 227 & 227 & 227 & $\mathbf{6 8 1}$ \\
\hline Jatirejo & 316 & 316 & 316 & $\mathbf{9 4 8}$ & 316 & 316 & 316 & $\mathbf{9 4 8}$ & 316 & 316 & 316 & $\mathbf{9 4 8}$ \\
\hline Janeng & 237 & 245 & 245 & $\mathbf{7 2 7}$ & 245 & 245 & 245 & $\mathbf{7 3 5}$ & 245 & 245 & 245 & $\mathbf{7 3 5}$ \\
\hline
\end{tabular}

Tabel 8: Volume Kebutuhan Air Irigasi Maksimum Untuk Pola Tata Tanam Alternatif ke-I, II dan III

\begin{tabular}{ccccccccccc}
\hline & \multicolumn{3}{c}{ Alternatif I } & \multicolumn{3}{c}{ Alternatif II } & \multicolumn{3}{c}{ Alternatif III } \\
\cline { 2 - 9 } & Bulan & Periode & $\begin{array}{c}\text { Volume Maks } \\
\left(\mathrm{m}^{3}\right)\end{array}$ & Bulan & Periode & $\begin{array}{c}\text { Volume Maks } \\
\left(\mathrm{m}^{3}\right)\end{array}$ & Bulan & Periode & $\begin{array}{c}\text { Volume Maks } \\
\left(\mathrm{m}^{3}\right)\end{array}$ \\
\hline I & Des & II & 279072.00 & Maret & II & 169207.19 & Maret & II & 154744.42 \\
II & Mei & I & 110113.10 & Juni & II & 143394.35 & Juni & III & 144070.87 \\
III & Juli & III & 49324.96 & Sept & II & 60740.47 & Sept & III & 58470.72 \\
\hline
\end{tabular}

\subsection{Pemilihan Alternatif}

Pemilihan alternatif akan dilihat dari beberapa aspek antara lain intensitas tanam yang paling tinggi, luas tanam paling optimal dari luas yang tersedia dan penggunaan debit paling tinggi dari suplai yang diberikan bendungan. Perbandingan intensitas tanam pada eksisting dan alternatif yang telah dioptimasi dapat dilihat pada Tabel 10. Perbandingan luas tanam pada eksisting dan alternatif setelah dioptimasi dapat dilihat pada Tabel 11. Sedangkan perbandingan debit kebutuhan air irigasi maksimum pada ketiga alternatif setelah optimasi ditampilkan pada Tabel 12.

Tabel 9: Perbandingan Intensitas Tanam Kondisi Eksisting Dan Alternatif Setelah Proses Optimasi

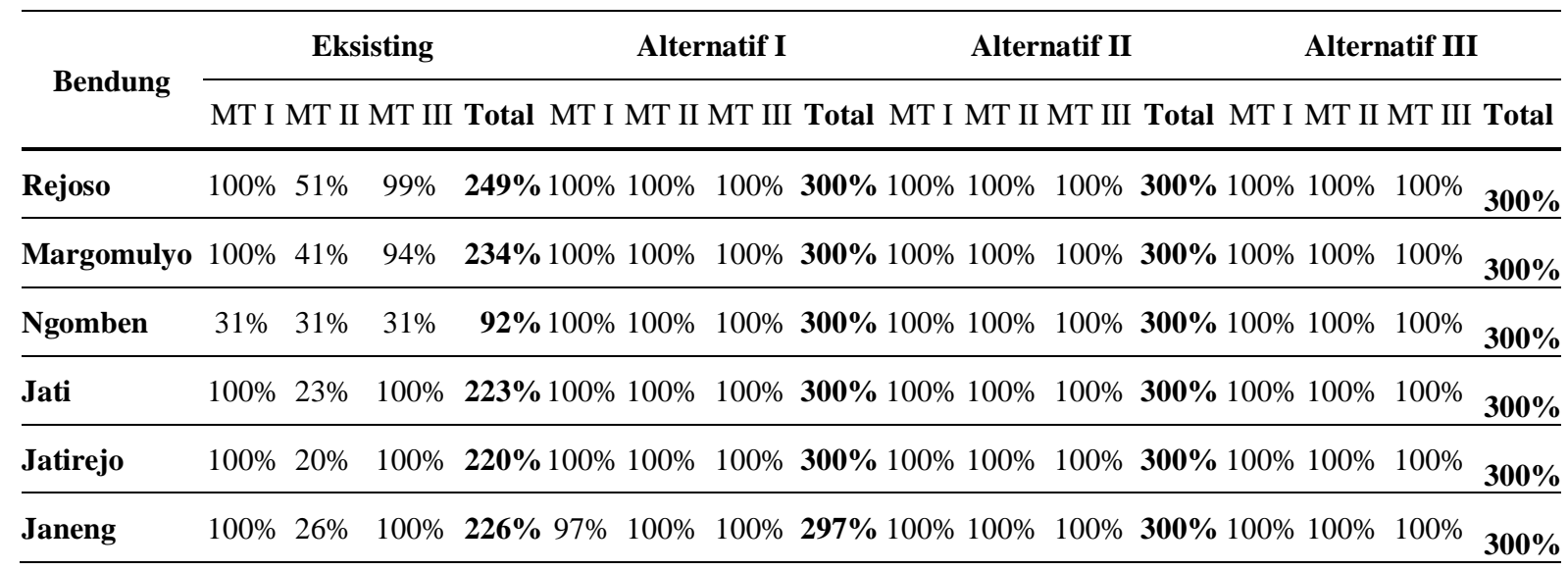


Tabel 10: Perbandingan Luas Tanam Kondisi Eksisting Dan Alternatif Setelah Proses Optimasi dalam hektar (ha)

\begin{tabular}{ccccccccccccccccccc}
\hline \multirow{2}{*}{ Bendung } & \multicolumn{4}{c}{ Eksisting (ha) } & \multicolumn{4}{c}{ Alternatif I (ha) } & \multicolumn{4}{c}{ Alternatif II (ha) } & \multicolumn{3}{c}{ Alternatif III (ha) } \\
\cline { 2 - 6 } & \multicolumn{3}{c}{ MT I MT II } & MT III Total MT I MT II & MT III Total MT I MT II & MT III Total MT I MT II MT III Total \\
\hline Rejoso & 465 & 236 & 459 & $\mathbf{1 1 6 0}$ & 465 & 465 & 465 & $\mathbf{1 3 9 5}$ & 465 & 465 & 465 & $\mathbf{1 3 9 5}$ & 465 & 465 & 465 & $\mathbf{1 3 9 5}$ \\
\hline Margomulyo & 154 & 63 & 144 & $\mathbf{3 6 1}$ & 154 & 154 & 154 & $\mathbf{4 6 2}$ & 154 & 154 & 154 & $\mathbf{4 6 2}$ & 154 & 154 & 154 & $\mathbf{4 6 2}$ \\
\hline Ngomben & 122 & 122 & 122 & $\mathbf{3 6 6}$ & 400 & 400 & 400 & $\mathbf{1 2 0 0}$ & 400 & 400 & 400 & $\mathbf{1 2 0 0}$ & 400 & 400 & 400 & $\mathbf{1 2 0 0}$ \\
\hline Jati & 227 & 53 & 227 & $\mathbf{5 0 7}$ & 227 & 227 & 227 & $\mathbf{6 8 1}$ & 227 & 227 & 227 & $\mathbf{6 8 1}$ & 227 & 227 & 227 & $\mathbf{6 8 1}$ \\
\hline Jatirejo & 316 & 62 & 316 & $\mathbf{6 9 4}$ & 316 & 316 & 316 & $\mathbf{9 4 8}$ & 316 & 316 & 316 & $\mathbf{9 4 8}$ & 316 & 316 & 316 & $\mathbf{9 4 8}$ \\
\hline Janeng & 245 & 63 & 245 & $\mathbf{5 5 3}$ & 237 & 245 & 245 & $\mathbf{7 2 7}$ & 245 & 245 & 245 & $\mathbf{7 3 5}$ & 245 & 245 & 245 & $\mathbf{7 3 5}$ \\
\hline
\end{tabular}

Tabel 11: Perbandingan Debit Kebutuhan Air Irigasi Maksimum Untuk Pola Tata Tanam Alternatif keI, II dan III

\begin{tabular}{cccccccccc}
\hline & \multicolumn{2}{c}{ Alternatif I } & \multicolumn{2}{c}{ Alternatif II } & \multicolumn{2}{c}{ Alternatif III } \\
\cline { 2 - 10 } MT & Bulan Periode & $\begin{array}{c}\text { Debit Maks } \\
\left(\mathrm{m}^{3} / \mathrm{dt}\right)\end{array}$ & \multicolumn{2}{c}{ Bulan Periode } & $\begin{array}{c}\text { Debit Maks } \\
\left(\mathrm{m}^{3} / \mathrm{dt}\right)\end{array}$ & Bulan Periode & $\begin{array}{c}\text { Debit Maks } \\
\left(\mathrm{m}^{3} / \mathrm{dt}\right)\end{array}$ \\
\hline I & Des & II & 3.23 & Maret & II & 1.96 & Maret & II & 1.79 \\
II & Mei & I & 1.27 & Juni & II & 1.66 & Juni & III & 1.67 \\
III & Juli & III & 0.57 & Sept & II & 0.70 & Sept & III & 0.68 \\
\hline
\end{tabular}

Dari ketiga alternatif yang direncanakan besar debit kebutuhan irigasi maksimumnya berselisih lumayan jauh dari suplai irigasi yang diberikan. Hal ini menandakan debit suplai air irigasi yang diberikan terlalu besar sehingga sisa suplai pada setiap periodenya juga cukup besar. Hasil analisa ketiga aspek tersebut maka dapat disimpulkan pola tata tanam alternatif ke-II dengan awal tanam bulan Desember periode III adalah alternatif yang paling sesuai sehingga direkomendasikan dan dianggap paling optimal untuk penggunaan air irigasi suplai dari Bendungan Semantok untuk memaksimalkan luas layanan irigasi pada daerah irigasi Kabupaten Nganjuk.

\section{Kesimpulan}

\subsection{Kesimpulan}

Berdasarkan perhitungan intensitas tanam kondisi eksisting Bendung Rejoso sebesar 249\%, Bendung Margomulyo sebesar 234\%, Bendung Ngomben sebesar 92\%, Bendung Jati sebesar 223\%, Bendung Jatirejo sebesar 220\% dan Bendung Janeng sebesar 226\%.

Dari analisa kebutuhan air eksisting dibandingkan dengan pemberian air dari bendung maka kondisi neraca air/water balance pada Bendung Rejoso kebutuhan air irigasi terpenuhi $72 \%$, Bendung Margomulyo terpenuhi 86\%, Bendung Ngomben terpenuhi 94\%, Bendung Jati terpenuhi 78\%, Bendung Jatirejo terpenuhi 58\% dan Bendung Janeng terpenuhi 50\%.

Setelah dilakukan optimasi, total luas tanam paling optimal pada alternatif ke-I (awal tanam November periode II) secara berurutan adalah 1395 ha, 462 ha, 1200 ha, 681 ha, 948 ha, dan 727 ha. Alternatif ke-II (awal tanam Desember periode III) secara berurutan adalah 1395 ha, 462 ha, 1200 ha, 681 ha, 948 ha, dan 735 ha. Serta alternatif ke-III (awal tanam Januari periode I) secara berurutan adalah 1395 ha, 462 ha pada, 1200 ha, 681 ha, 948 ha, dan 735 ha.

Total intensitas tanam setelah optimasi pada alternatif ke-I yaitu seluruh bendung sebesar $300 \%$ kecuali Bendung Janeng 297\% sedangkan untuk alternatif ke-II dan III seluruhnya telah mencapai $300 \%$. Kondisi kebutuhan air irigasi maksimum pada alternatif ke-I dari masa tanam I,II dan III adalah sebesar $3,23 \mathrm{~m}^{3} / \mathrm{dt} ; 1,27 \mathrm{~m}^{3} / \mathrm{dt}$; dan $0,57 \mathrm{~m}^{3} / \mathrm{dt}$, pada alternatif ke-II sebesar $1,96 \mathrm{~m}^{3} / \mathrm{dt} ; 1,66 \mathrm{~m}^{3} / \mathrm{dt}$; dan $0,70 \mathrm{~m}^{3} / \mathrm{dt}$, serta pada alternatif ke-III sebesar $1,79 \mathrm{~m}^{3} / \mathrm{dt} ; 1,67 \mathrm{~m}^{3} / \mathrm{dt}$ dan $0,68 \mathrm{~m}^{3} / \mathrm{dt}$. Maka alternatif yang dipilih adalah alternatif pola tata tanam ke-II dengan pola padi-padi-palawija dimulai awal tanam pada Desember periode III. 


\subsection{Saran}

Suplai yang diberikan bersisa cukup banyak. Sebaiknya suplai yang diberikan bendungan tiap periodenya dikurangi atau dimanfaatkan dengan cara lain. Perlu dilakukan tinjauan lebih lanjut untuk menghitung keuntungan hasil produksi untuk setiap tanaman pada setiap alternatif. Selain itu metode program linier sebaiknya tidak digunakan untuk menganalisa suatu program optimasi yang sangat kompleks. Apabila dilakukan dengan metode lain dengan batasan yang lebih detail akan menampilkan hasil lebih akurat.

\section{Ucapan Terimakasih}

Penulis mengucapkan terimakasih atas akses data dalam studi terkait Bendungan Semantok ini kepada Satuan Kerja Bendungan BBWS Brantas, Konsultan Supervisi PT. Caturbina Guna Persada (JO), PT. Arga Pasca Rencana, dan PT. Wecon serta Juru dari Dinas PU Pengairan Daerah UPTD Kecamatan Gondang Nganjuk.

\section{Daftar Pustaka}

[1] S. P. Sicca, "BPS: Jumlah Penduduk Bekerja Triwulan I 2018 Sebanyak 127,07 Juta," tirto.id, 8 Mei 2018. [Online]. Available: https://tirto.id/bps-jumlah-penduduk-bekerja-triwulan-i-2018sebanyak-12707-juta-cJ5D. [Accessed Mei 2019].

[2] R. W. Sayekti, "Model Optimasi Alternatif Pola Tanam untuk Mendapatkan Luas Tanam dan Keuntungan yang Optimum (Studi Kasus di Dam Jatimlerek, Kabupaten Jombang)," Jurnal Teknik Pengairan: Journal of Water Resources Engineering, vol. 1, no. 2, pp. 115-126, 2012.

[3] I. Y. Fakultas Teknologi Pertanian, "Studi Pemanfaatan Air Waduk Semantok Fasilitasi Perijinan Rencana Pembangunan Bendungan Semantok," Instiper Yogyakarta, Yogyakarta, 2018.

[4] L. M. Limantara, Rekayasa Hidrologi - Edisi Revisi, Yogyakarta: ANDI, 2018.

[5] Soewarno, Hidrologi Aplikasi Metode Statistik untuk Analisa Data, Bandung: Nova, 1995.

[6] B. Lakitan, Dasar-dasar Klimatologi, Jakarta: PT Raja Grafindo Persada, 1997.

[7] D. P. Umum, Standar Perencanaan Irigasi - Kriteria Perencanaan Bagian Jaringan Irigasi KP01, Jakarta: Badan Penerbit Departemen, 2013.

[8] L. M. Limantara, Hidrologi Praktis, Bandung: Lubuk Agung, 2010.

[9] M. Bardan, Irigasi, Yogyakarta: Graha Ilmu, 2014.

[10] R. Wirosoedarmo, Dasar-Dasar Irigasi Pertanian, Malang: Universitas Brawijaya, 1985.

[11] Bening, UPTD PSDA, "Rekapitulasi Debit Pemberian Bendung," Kabupaten Nganjuk, 2018.

[12] L. M. Limantara and W. Soetopo, Pengantar Manajemen Teknik Sumber Daya Air, Malang: CV Citra Malang, 2009. 